\title{
PRODUKSI RUMPUT (Pennisetum purpureum cv. Mott) DEFOLIASI I PERTAMA DENGAN JENIS PUPUK YANG BERBEDA
}

\author{
Dylla Pramanti Rukmana Dewi \\ Mahasiswa Program Studi Ilmu Ternak Fakultas Peternakan \\ Universitas Islam Balitar \\ Jl. Majapahit No. 04 Kota Blitar
}

\begin{abstract}
The aims of the study is to determine the effect different fertilizer types on Pennisetum purpureum cv. Mott grass production. A randomized completely design was applied with 4 treatment and 16 replication. The treatment consist of $P O$ - control (using basic fertilizer SP 36), $P 1=$ basic fertilizer and $765 \mathrm{~kg}$ per hectare of organic fertilizer, $P 2=$ basic fertilizer and $250 \mathrm{~kg}$ per hectare of urea fertilizer, $P 3=$ basic fertilizer and $720 \mathrm{~kg}$ per hectare of $N-P-K$ fertilizer. Observed variables include leaf colour indeks, fresh weight, dry weight productions, higher plants, number of chicks, stem circumference, hill circumference, leaf length, leaf width, and number of leaf. The conclusion based on the result were the treatment not significant $(P>0,05)$ on all variabel because due to the equalization of the nitrogen element given to the plant. It's suggested to use manure for more efficient production.
\end{abstract}

Keyword: Pennisetum purpureum cv. Mott, fertilizer, nitrogen.

\section{PENDAHULUAN}

Sapi yang merupakan hewan mamalia berlambung jamak (polygastrik) sangat memerlukan serat kasar yang terkandung dalma hijauan makanan ternak. Serat kasar berfungsi menjaga alat pencernaan agar tetap dapat bekerja dengan baik (Sugeng, 2007). Hijauan pakan ternak dibutuhkan secara kontinyu, dengan demikian diperlukan jenis hijauan pakan ternak yang mampu berproduksi tinggi untuk memenuhi kebutuhan hijauan secara berkelanjutan. Rumput Pennisetum purpureum cv. Mott menjadi alternatif rumput pakan ternak yang banyak dibudidayakan sebagai tanaman utama ataupun sebagai tanaman tumpang sari. Rumput ini banyak diminati karena tahan kekeringan, memiliki kandungan zat gizi yang cukup tinggi serta memiliki palatabilitas yang tinggi bagi ternak ruminansia (Lasamadi, 2013).

Produktivitas tanaman dipengaruhi oleh unsur hara. Apabila hara dalam tanah tidak mencukupi kebutuhan tanaman, maka diperlukan penambahan melalui pemupukan (Kusuma, 2014). Pupuk mampu memperbaiki struktur tanah dari yang mulanya padat menjadi gembur. Siahaya (2007) menyatakan bahwa pemupukan adalah kegiatan menggemburkan tanah di sekitar tanaman dengan maksud memperbaiki sifat fisik tanah yang nantinya akan memacu pertumbuhan tanaman.

Menurut Kusuma (2014) pemupukan akan lebih efektif apabila menggunakan jenis pupuk yang tepat. Pertumbuhan tanaman dapat dioptimalkan dengan pemberian pupuk yang tepat. Untuk mengusahakan suatu lahan hijauan makanan ternak (HMT) agar produktif dan efisien perlu memperhatikan habitat dari rumput yang akan ditanam, reaksi terhadap jenis tanah, dalamnya lapisan tanah, drainase dan unsur hara yang terkandung dalam tanah (Yani, 2008).

Pada saat pengolahan lahan, ditambahkan pupuk dasar untuk meningkatkan $\mathrm{pH}$ tanah. Menurut Lembah Gogoniti (2017) pupuk dasar yang diberikan adalah pupuk kandang dengan dosis 3 ton per hektar lahan. Berbeda dengan Sirait, A. Tarigan, dan K. Simanihuruk (2015) 
yang menyatakan bahwa pupuk kandang yang digunakan sebagai pupuk dasar sebanyak 5 ton per hektar lahan dan pupuk kimia diberikan pada saat tanaman berumur dua minggu.

Menurut Siahaya (2007) untuk pupuk dasar dapat pula menggunakan pupuk NPK atau pupuk TSP, dengan dosis NPK $(30-100)$ g per tanaman. Berdasarkan penelitian yang dilakukan oleh Sigar, dkk., (2014) pupuk TSP sebagai pupuk dasar diberikan sebanyak $75 \mathrm{~kg}$ per hektar lahan. Selain pupuk dasar, diperlukan penambahan pupuk untuk menunjang pertumbuhan tanaman. Adapun jenis-jenis pupuk adalah sebagai berikut:

a. Pupuk Organik: berdasarkan cara pembuatannya, pupuk dibedakan menjadi dua yaitu pupuk organik dan pupuk anorganik. Pupuk anorganik lebih mudah didapatkan tetapi harganya relatif mahal dan apabila digunakan secara terus menerus dapat menyebabkan kerusakan lingkungan. Pemanfaatan pupuk organik merupakan salah satu alternatif yang tepat dalam usaha budidaya hijauan pakan. Menurut Wikipedia (2017) penggunaan pupuk organik dalam jangka panjang dapat meningkatkan produktivitas lahan dan mencegah gradasi lahan. Selain itu peranannya cukup besar terhadap perbaikan sifat fisik, kimia, niologi tanah serta lingkungan.

b. Pupuk Majemuk: merupakan pupuk campuran yang umumnya mengandung lebih dari satu macam unsur mikro maupun makro terutama unsur N, P, dan K (Kusuma, 2014). Penggunanan pupuk NPK dapat menjadi solusi alternatif dalam meningkatkan pertumbuhan tanaman hijauan. Penggunaan pupuk NPK diharapkan dapat memberikan kemudahan dalam pengaplikasian di lapangan dan dapat meningkatkan kandungan unsur hara yang dibutuhkan di dalam tanah serta dapat dimanfaatkan langsung oleh tanaman (Kusuma, 2014). Menurut Siahaya (2007) pupuk NPK umumnya digunakan sebagai pupuk dasar dengan dosis antara $(30-100)$ gr per tanaman. Kusuma (2014) menyatakan bahwa untuk rumput gajah agar menggunakan jenis pupuk majemuk dengan kandungan NPK 16:16:16 atau 15:15:6 dengan dosis $300 \mathrm{~kg}$ per ha- ${ }^{1}$.

c. Pupuk Tunggal: adalah pupuk yang didalamya hanya terkandung satu unsur hara saja. Contoh pupuk tunggal adalah pupuk nitrogen (urea, Za), pospor (TSP, SP-36), dan kalium (KCL). Urea merupakan pupuk buatan hasil persenyawaan $\mathrm{NH}_{4}$ (ammonia) dengan $\mathrm{CO}_{2}$. Kandungan $\mathrm{N}$ total dalam pupuk urea adalah $46 \%$. Artinya setiap $100 \mathrm{~kg}$ Urea, di dalamnya terkandung $46 \mathrm{~kg}$ unsur hara $\mathrm{N}$.

Pemahaman tentang kebutuhan tanaman atas pupuk menjadi kunci keberhasilan budidaya. Pemupukan sebaiknya dilakukan berdasarkan asas keseimbangan. Pemberian pupuk yang mengandung unsur hara tertentu jika berlebihan akan mengganggu penyerapan unsur lainnya. Hasil maksimal dari pemupukan akan diperoleh jika dilakukan dengan cara, dosis, dan jenis pupuk yang tepat (Kusuma, 2014). Salah satunya adalah kebutuhan akan unsur nitrogen oleh tanaman yang dapat diberikan melalui pemupukan.

Menentukan kebutuhan pupuk bagi tanaman tidak akan menghasilkan jumlah yang pasti, tetapi dengan metode yang benar kebutuhan riil tanaman dapat didekati. Kebutuhan pupuk yang rasional umumnya didasarkan pada jenis tanaman dan produksi yang ingin dicapai, ketersediaan hara tanah, jenis pupuk yang digunakan, serta efisiensi pemupukan.

Penafsiran kebutuhan pupuk yang paling sering digunakan adalah berdasarkan hasil percobaan pemupukan. Berdasarkan hasil penelitian yang sudah dilakukan akan diketahui dosis mana yang menghasilkan produksi tertinggi yang akan dijadikan patokan kebutuhan pupuk.

Petani di lapangan lebih banyak menggunakan pupuk nitrogen untuk pemupukan rumput Pennisetum purpureun cv. Mott. Tanaman sangat memerlukan nitrogen yang berfungsi untuk pembentukan klorofil. Nitrogen juga berperan dalam pembentukan protein, hormon, vitamin, enzim, dan berperan juga untuk memacu pertumbuhan batang tanaman 
(Palupi, 2011). Unsur nitrogen akan mempengaruhi warna hijau daun. Ketika tanaman tidak mendapatkan cukup nitrogen, warna hijau daun akan memudar dan menguning. Kelebihan unsur nitrogen juga akan menunda pembungaan dan pembuahan (Palupi, 2011).

Kebutuhan Pennisetum purpureum cv Mott akan pupuk N sekitar $150 \mathrm{~kg} / \mathrm{ha}$ (Sigar, dkk., 2014). Santia, Anis, dan Kaunang (2017) berpendapat bahwa setelah tanaman berumur satu minggu, akan diberi pupuk urea sebanyak $150 \mathrm{~kg}$ per hektar. Sedangkan Yani (2008) menyatakan bahwa umumnya petani menggunakan urea untuk pemupukan rumput gajah sebanyak $250 \mathrm{~kg} / \mathrm{ha}$ atau setara dengan $115 \mathrm{~kg}$ nitrogen/ha. Jika ditinjau dari jumlah nitrogen murni yang biasa diberikan, dapat diasumsikan bahwa kubutuhan pupuk organik sebanyak $765 \mathrm{~kg} / \mathrm{ha}$ dan pupuk NPK sebanyak $720 \mathrm{~kg} / \mathrm{ha}$.

Untuk memenuhi unsur hara bagi tanaman, diperlukan percobaan dengan mengaplikasikan berbagai jenis pupuk yang memiliki komposisi unsur hara berbeda. Pupuk dengan kandungan unsur dan porporsi yang sesuai diharapkan mampu meningkatkan produktivitas rumput Pennisetum purpureun cv. Mott sehingga mampu mencukupi kebutuhan pakan ternak.

\section{METODE PENELITIAN}

Penelitian ini dilakukan di Dusun Campur Janggrang, Desa Campur Darat, Kecamatan Campur Darat, Kabupaten Tulungagung. Waktu yang diperlukan untuk penelitian selama enam puluh (60) hari yang dimulai tanggal 1 Juli sampai dengan 29 Agustus 2017.

Materi yang digunakan untuk penelitian adalah spesies rumput Pennisetum purpureun cv. Mott. Alat dan bahan yang digunakan dalam penelitian ini adalah bibit rumput Pennisetum purpureun $\mathrm{c} v$. Mott, polybag ukuran $(50 \times 50) \mathrm{cm}$, tanah, sekam, dan kotoran kambing, cangkul, pisau, air, tangki air (gembor), gayung, pupuk SP - 36, pupuk organik merk Petroganik, pupuk nitrogen merk Urea, pupuk kimia NPK Mutiara, plang nama, meteran, timbangan digital dengan skala $0,01 \mathrm{~g}, 1 \mathrm{~g}$, dan $0,01 \mathrm{~kg}$.

Penelitian dilakukan secara eksperimen yakni melakukan percobaan berbagai jenis pupuk pada rumput Pennisetum purpureum cv. Mott defoliasi pertama, dengan menyetarakan kebutuhan nitrogen. Perlakuan yang diujikan adalah sebagai berikut:

- P0 = hanya pupuk dasar SP - 36 (kontrol).

- P1= pupuk dasar dan pupuk organik dengan dosis $765 \mathrm{~kg} / \mathrm{ha}$.

- P2 = pupuk dasar dan pupuk urea dengan dosis $250 \mathrm{~kg} / \mathrm{ha}$.

- P3 = pupuk dasar dan pupuk NPK dengan dosis $720 \mathrm{~kg}$ per ha.

Masing-masing perlakuan diulang sebanyak 16 kali dan sehingga diperoleh 64 tanaman. Satuan percobaan berupa satu unit tanaman.

a. Media tanam yang digunakan adalah polybag berukuran $(50 \times 50) \mathrm{cm}$. Tanah yang digunakan dicampur sekam dan kotoran kambing dengan perbandingan volume $1: 1$. Bibit yang ditanam berasal dari stek batang dengan berat (32 - 44) gr yang terdiri dari (10 - 12) ruas. Stek batang ditanam dengan posisi miring.

b. Pengairan atau penyiraman dilakukan setiap hari pada awal penanaman selama tujuh hari dengan menggunakan tangki air (gembor). Penyiraman berikutnya dilakukan berdasarkan ketersediaan air tanah. Air yang digunakan berasal dari air sumur. Tanaman disiram dengan proporsi air yang sama.

c. Pupuk SP - 36 sebagai pupuk dasar dengan dosis $96 \mathrm{~kg} / \mathrm{ha}$ dicampurkan pada media tanam. Pemupukan selanjutnya dilakukan pada 14 hari setelah tanam dengan dosis sesuai masing-masing perlakuan yang telah ditentukan. Pupuk disebar melingkar disekitar batang dengan jarak $\pm 5 \mathrm{~cm}$. 
d. Rumput Pennisetum purpureum cv. Mott dipanen pada hari ke 60 setelah tanam, dengan cara memotong rumpun dan menyisakan batang setinggi $10 \mathrm{~cm}$ di atas tanah, kemudian rumput ditimbang dan dilakukan pengambilan data.

e. Variabel yang diamati dalam penelitian ini meliputi:

- Tinggi tanaman: Tinggi tanaman diukur pada batang tanaman tertinggi dimulai dari pangkal batang (permukaan tanah) sampai titik tumbuh tanaman (ujung daun yang lurus ke atas sejajar batang) mengacu pada pendapat Zahroh, Muizzudin dan Chamisijatin (2016).

- Jumlah daun: Jumlah daun (helai), dihitung semua daun yang berbentuk sempurna pada tiap - tiap rumpun (Sandiah, Pasolon, dan Sabaruddin, 2011).

- Panjang daun: Panjang daun $(\mathrm{cm})$, diukur pada daun terpanjang mulai dari colar (ketiak daun) sampai ujung daun (Sirait, A. Tarigan, dan K. Simanihuruk, 2015).

- Lebar daun: Lebar daun $(\mathrm{cm})$, diukur pada bagian tengah daun yang terlebar (Sirait, A. Tarigan, dan K. Simanihuruk, 2015).

- Jumlah anakan: Jumlah anakan (batang per rumpun) dihitung pada tanaman yang telah mempunyai anakan yang berdaun dan membuka sempurna (Sandiah, Pasolon, dan Sabaruddin, 2011).

- Berat basah segar: Dilakukan pada saat panen dengan cara menimbang seluruh bagian tanaman kecuali akar dengan menggunakan timbangan digital dengan ketelitian 0, $01 \mathrm{~kg}$ (Zahroh, Muizzudin dan Chamisijatin, 2016).

- Berat kering matahari (layu): Dilakukan pada saat panen dengan cara mengeringkan seluruh bagian tanaman kecuali akar di bawah sinar matahari langsung mulai pukul 08.00 sampai dengan pukul 11.00 dan dibalik setiap 1 jam. Kemudian ditimbang beratnya menggunakan timbangan digital dengan ketelitian $0,01 \mathrm{~kg}$.

- Indeks hijau daun: Pengukuran indeks hijau daun dilakukan dengan memilih satu daun dari rumpun secara acak, dan bagian tengah daun diletakkan di atas bagan warna daun (Gani, 2007).

- Lingkar Batang: Lingkar batang $(\mathrm{cm})$ dilakukan dengan cara melingkarkan alat ukur pada bagian pangkal batang terbesar dalam satu rumpun.

- Lingkar Rumpun: Lingkar rumpun (cm) dilakukan dengan cara melingkarkan alat ukur disekeliling rumpun.

Data yang diperoleh dianalisis dengan sidik ragam (ANOVA), apabila berbeda nyata atau sangat nyata dilakukan Uji Jarak Berganda Duncan (Steel dan Torrie, 1995). Model matematika yang digunakan adalah sebagai berikut :

Keterangan :

$$
Y i j=\mu+\alpha i+€ i j
$$

$\mathrm{i} \quad=1,2,3 \ldots \ldots \ldots \ldots . . \mathrm{p}$ (jumlah perlakuan).

$\mathrm{J} \quad=1,2,3,4 \ldots \ldots \ldots \ldots$ (jumlah ulangan).

Yij = Produktivitas rumput Gajah ke- $\mathrm{j}$ yang memperoleh perlakuan ke- $\mathrm{i}$

$\mu \quad=$ Nilai tengah (rata-rata populasi)

$\alpha \mathrm{i} \quad=$ Pengaruh pemberian pupuk taraf ke- $\mathrm{i}$

$€ \mathrm{ij}=$ Galat percobaan pada satuan percobaan ulangan ke- $\mathrm{j}$ yang memperoleh perlakuan ke- i.

\section{HASIL DAN PEMBAHASAN}




\section{Indeks Hijau Daun (IHD)}

Pengambilan data IHD dilakukan setiap 15 hari. Hal ini dilakukan guna mengetahui pertumbuhan tanaman serta kecukupan unsur hara yang diperlukan oleh tanaman. Berdasarkan data analisis sidik ragam, menunjukkan bahwa pemberian jenis pupuk yang berbeda tidak berpengaruh nyata $(\mathrm{P}>0,05)$ terhadap tinggi tanaman rumput Pennisetum purpureum $c v$. Mott. Nilai IHD yang diperoleh termasuk dalam kategori baik, yang artinya kebutuhan unsur nitrogen pada tanaman telah terpenuhi dari pemberian pupuk pupuk sesuai dengan masing - masing perlakuan. Nilai IHD pada rumput Pennisetum purpureum cv. Mott hasil penelitian disajikan pada Tabel 1 .

\begin{tabular}{cccccc}
\hline \multirow{2}{*}{ Perlakuan } & \multicolumn{4}{c}{ Waktu Pengambilan Data } & \multirow{2}{*}{ Rata - rata } \\
\cline { 2 - 5 } & $\mathbf{1 5} \mathbf{h s t}$ & $\mathbf{3 0} \mathbf{h s t}$ & $\mathbf{4 5} \mathbf{h s t}$ & $\mathbf{6 0} \mathbf{~ h s t}$ & \\
\hline $\mathbf{1}$ & $3,32^{\mathrm{a}}$ & $3,26^{\mathrm{a}}$ & $3,42^{\mathrm{a}}$ & $3,39^{\mathrm{a}}$ & 3,84 \\
\hline $\mathbf{2}$ & $3,20^{\mathrm{a}}$ & $3,22^{\mathrm{a}}$ & $3,37^{\mathrm{a}}$ & $3,87^{\mathrm{a}}$ & 3,41 \\
\hline $\mathbf{3}$ & $3,06^{\mathrm{a}}$ & $3,37^{\mathrm{a}}$ & $3,29^{\mathrm{a}}$ & $3,89^{\mathrm{a}}$ & 3,40 \\
\hline $\mathbf{4}$ & $3,23^{\mathrm{a}}$ & $3,43^{\mathrm{a}}$ & $3,46^{\mathrm{a}}$ & $3,87^{\mathrm{a}}$ & 3,49
\end{tabular}

Superskrip yang sama pada baris yang sama menunjukkan berbeda nyata $(\mathrm{P}>0,05)$.

\section{Berat Segar}

Berat segar merupakan akumulasi dari keseluruhan variable yang dihitung pada saat pemanenan. Berat segar menjadi luaran dari semua proses penanaman hijauan pakan ternak yang berperan langsung kepada ternak ruminansia. Berat segar rumput Pennisetum purpureum $c v$. Mott defoliasi pertama dengan jenis pupuk yang bebeda disajikan pada tabel dibawah ini:

\begin{tabular}{ccccc} 
Berat & \multicolumn{4}{c}{ Perlakuan } \\
\cline { 2 - 5 } Segar $(\mathbf{g})$ & $\mathbf{1}$ & $\mathbf{2}$ & $\mathbf{3}$ & $\mathbf{4}$ \\
\cline { 2 - 5 } & $464,06^{\mathrm{a}}$ & $369,37^{\mathrm{a}}$ & $380,01^{\mathrm{a}}$ & $365,96^{\mathrm{a}}$ \\
\hline
\end{tabular}

Superskrip yang sama pada baris yang sama menunjukkan berbeda nyata $(\mathrm{P}>0,05)$.

Berdasarkan data pada tabel di atas, berat segar tertinggi diperoleh pada perlakuan kontrol tanpa pupuk yakni 464, 06 gram per rumpun. Berat segar tidak dipengaruhi secara nyata $(\mathrm{P}>0,05)$ oleh perlakuan jenis pupuk yang berbeda. Berat segar tertinggi tanaman yang diperoleh (464, $06 \mathrm{~g}$ ) berada jauh dibawah asumsi Paat dan Taulu (2012) yakni 4, $69 \mathrm{~kg}$ per rumpun tanaman.

\section{Berat Kering Matahari}

Berat kering matahari yang diperoleh saat penelitian disajikan pada Tabel 3 dibawah ini:

\begin{tabular}{lcccc} 
& \multicolumn{4}{c}{ Perlakuan } \\
\cline { 2 - 5 } Berat Kering & $\mathbf{1}$ & $\mathbf{2}$ & $\mathbf{3}$ \\
\cline { 2 - 5 } & $426,8^{\mathrm{a}}$ & $329,2^{\mathrm{a}}$ & $346,8^{\mathrm{a}}$ & $332,8^{\mathrm{a}}$
\end{tabular}

Superskrip yang sama pada baris yang sama menunjukkan berbeda nyata $(\mathrm{P}>0,05)$.

Berat kering matahari (layu) rumput Pennisetum purpureum cv. Mott sangat penting untuk diketahui karena sesuai dengan kondisi di lapang rumput yang diberikan peternak kepada ternak yang dipelihara. Hijauan yang akan diberikan pada ternak perlu dilayukan untuk mengurangi kadar air pada rumput yang dapat menyebabkan diare pada ternak. 
Berdasarkan data analisis sidik ragam dapat disimpulkan bahwa berat kering matahari tidak dipengaruhi secara nyata $(\mathrm{P}>0,05)$ oleh jenis pupuk yang berbeda.

\section{Jumlah Anakan}

Jumlah anakan yang rumput Pennisetum purpureum cv. Mott dengan jenis pupuk yang berbeda disajikan pada tabel dibawah ini:

\begin{tabular}{cccc}
\hline \multicolumn{4}{c}{ Perlakuan } \\
\hline $\mathbf{1}$ & $\mathbf{2}$ & $\mathbf{3}$ & $\mathbf{4}$ \\
\hline $\mathbf{1 1}, \mathbf{9}^{\mathrm{a}}$ & $12^{\mathrm{a}}$ & $10,4^{\mathrm{a}}$ & $10,6^{\mathrm{a}}$ \\
\hline
\end{tabular}

Superskrip yang sama pada baris yang sama menunjukkan berbeda nyata $(\mathrm{P}>0,05)$.

Jumlah anakan tertinggi diperoleh pada perlakuan pupuk organik $(12,06)$. Hal ini dimungkinkan karena unsur hara yang terkandung dalam pupuk organik lebih lengkap. Didukung oleh Lasamadi (2013) yang menyatakan bahwa unsur nitrogen yang terkandung dalam pupuk organik sangat besar kegunaannya bagi tanaman untuk pertumbuhan dan perkembangan, antara lain membuat daun tanaman lebih hijau segar dan banyak mengandung klorofil yang mempunyai peranan sangat penting dalam proses fotosintesis, mempercepat pertumbuhan tanaman (tinggi, jumlah anakan, cabang, dan lain - lain) serta menambah kandungan protein tanaman.

Analisis sidik ragam pada data jumlah anakan menunjukkan bahwa jumlah anakan tidak berpengaruh nyata $(\mathrm{P}>0,05)$ oleh perlakuan jenis pupuk yang berbeda. Jumlah anakan yang diperoleh saat penelitian lebih tinggi dari jumlah anakan yang dihasilkan saat penelitian Kusuma (2014) sebanyak $(7,5-10,4)$ anakan, namun lebih rendah dari jumlah anakan pada penelitian Sirait, A. Tarigan dan K. Simanihuruk (2015) yang menghasilkan (20, 4 - 24, 9) anakan dan Lasamadi (2013) yang menghasilkan (21, 4-29, 8) anakan.

\section{Lingkar Batang}

Perkembangan batang tanaman dipengaruhi oleh unsur nitrogen sesuai dengan pendapat Palupi (2011) yang menyatakan bahwa nitrogen adalah komponen pembentuk protein, hormon, klorofil, vitamin, enzim. Data analisis sidik ragam menunjukkan bahwa pemberian jenis pupuk yang berbeda tidak berpengaruh nyata $(\mathrm{P}>0,05)$ terhadap lingkar batang rumput Pennisetum purpureum cv. Mott defoliasi pertama.

Lingkar batang rumput Pennisetum purpureum $c v$. Mott dengan jenis pupuk yang berbeda disajikan dalam Tabel 5. dibawah ini:

\begin{tabular}{cccc}
\hline \multicolumn{4}{c}{ Perlakuan } \\
\hline $\mathbf{1}$ & $\mathbf{2}$ & $\mathbf{3}$ & $\mathbf{4}$ \\
\hline $\mathbf{7 , 4 ^ { \mathrm { a } }}$ & $6,7^{\mathrm{a}}$ & $6,7^{\mathrm{a}}$ & $7^{\mathrm{a}}$
\end{tabular}

Superskrip yang sama pada baris yang sama menunjukkan berbeda nyata $(\mathrm{P}>0,05)$.

Lingkar batang tertinggi diperoleh pada perlakuan kontrol tanpa pupuk yakni 7, $4 \mathrm{~cm}$. Lingkar batang yang diperoleh lebih tinggi dari lingkar batang hasil penelitian Lasamadi (2013) yakni $(3,64-4,72) \mathrm{cm}$.

\section{Lingkar Rumpun}

Lingkar rumput Pennisetum purpureum cv. Mott hasil penelitian dengan jenis pupuk yang berbeda disajikan dalam Tabel 6 . 


\section{\begin{tabular}{lcccc} 
& \multicolumn{5}{c}{ Perlakuan } \\
\cline { 2 - 5 } Lingkar Rumpun (cm) & $\mathbf{1}$ & $\mathbf{2}$ & $\mathbf{3}$ & $\mathbf{4}$ \\
\cline { 2 - 5 } & $90,88^{\mathrm{a}}$ & $87,03^{\mathrm{a}}$ & $78,65^{\mathrm{a}}$ & $86,48^{\mathrm{a}}$ \\
\hline
\end{tabular}}

Superskrip yang sama pada baris yang sama menunjukkan berbeda nyata $(\mathrm{P}>0,05)$.

Lingkar rumpun merupakan tanda terpenuhinya kebutuhan tanaman akan unsur nitrogen sebagai pemacu pertumbuhan daun dan batang (Palupi, 2011). Karena komponen utama yang mempengaruhi lingkar rumpun adalah batang anakan dan daun.

Analisis sidik ragam menunjukkan bahwa perlakuan jenis pupuk yang berbeda tidak berpengaruh secara nyata $(\mathrm{P}>0,05)$ terhadap lingkar rumpun Pennisetum purpureum $c v$. Mott defoliasi pertama. Rumpun terbesar diperoleh pada perlakuan kontrol tanpa pupuk yakni $(90,88) \mathrm{cm}$.

\section{Tinggi Tanaman}

Nitrogen berperan dalam pertumbuhan vegetative tanaman, termasuk tinggi tanaman. Hal ini dibuktikan dengan tinggi tanaman rumput Pennisetum purpureum cv. Mott hasil penelitian hampir sama, dikarenakan kandungan nitrogen yang diberikan juga dalam dosis yang sama.

Data tinggi tanaman pada Tabel 7. menunjukkan rata - rata tinggi tanaman pada saat penelitian pada empat perlakuan yang berbeda. Tabelnya disajikan di bawah ini:

\begin{tabular}{ccccc} 
& \multicolumn{4}{c}{ Perlakuan } \\
\cline { 2 - 5 } Tinggi Tanaman $(\mathbf{c m})$ & $\mathbf{1}$ & $\mathbf{2}$ & $\mathbf{3}$ & $\mathbf{4}$ \\
\cline { 2 - 5 } & $100,05^{\mathrm{a}}$ & $95,52^{\mathrm{a}}$ & $97,56^{\mathrm{a}}$ & $99,77^{\mathrm{a}}$ \\
\hline
\end{tabular}

Superskrip yang sama pada baris yang sama menunjukkan berbeda nyata $(\mathrm{P}>0,05)$.

Analisis sidik ragam pada tinggi tanaman menunjukkan bahwa pemberian jenis pupuk yang berbeda tidak berpengaruh nyata $(\mathrm{P}>0$, 05) terhadap tinggi tanaman rumput Pennisetum purpureum cv. Mott defoliasi pertama. Pada perlakuan kontrol menunjukkan tinggi tanaman yang paling tinggi diantara empat perlakuan yang diujikan, yakni $(100,05)$ $\mathrm{cm}$. Tinggi tanaman ini berada dibawah tinggi tanaman hasil penelitian Lasamadi (2013) yakni $(108,2$ - 125, 4) cm, Kusuma (2014) yakni $(148,90$ - 196, 55) cm, dan Rellam, dkk., (2017) yakni $(142,76-169,0) \mathrm{cm}$. Namun lebih tinggi dari tinggi tanaman hasil penelitian Sirait, A. Tarigan dan K. Simanihuruk (2015) yang menghasilkan $(36,8-80$, 7) cm.

\section{Panjang Daun}

Panjang daun dipengaruhi oleh unsur nitrogen, sebab unsur nitrogen merupakan unsur utama pembentuk zat hijau daun yang berguna untuk kegiatan fotosintesis tanaman. Panjang daun rumput Pennisetum purpureum cv. Mott hasil penelitian disajikan pada tabel dibawah ini:

\begin{tabular}{lcccc}
\hline \multirow{2}{*}{ Panjang Daun (cm) Perlakuan } \\
\cline { 2 - 5 } & $\mathbf{1}$ & $\mathbf{2}$ & $\mathbf{3}$ & $\mathbf{4}$ \\
\cline { 2 - 5 } & $77,36^{\mathrm{a}}$ & $72,22^{\mathrm{a}}$ & $76,25^{\mathrm{a}}$ & $77,15^{\mathrm{a}}$ \\
\hline
\end{tabular}

Superskrip yang sama pada baris yang sama menunjukkan berbeda nyata $(\mathrm{P}>0,05)$.

Analisis sidik ragam menunjukkan bahwa panjang daun rumput Pennisetum purpureum $c v$. Mott tidak dipengaruhi nyata $(\mathrm{P}>0,05)$ oleh perlakuan jenis pupuk yang berbeda. Panjang daun ini lebih tinggi dari hasil penelitian Sirait, A. Tarigan dan K. 
Simanihuruk (2015) yakni $(56,5$ - 59, 9) cm, hasil penelitian Rellam, dkk., (2017) yang menghasilkan panjang daun $(44,16-53,33 \mathrm{~cm})$, dan Lasamadi (2013) yang memperoleh $(50,2-61,4) \mathrm{cm}$

\section{Lebar Daun}

Lebar daun rumput Pennisetum purpureum cv. Mott defoliasi pertama dengan jenis pupuk yang berbeda disajikan pada tabel dibawah ini:

\begin{tabular}{lcccc} 
& \multicolumn{4}{c}{ Perlakuan } \\
\cline { 2 - 5 } Lebar Daun (cm) & $\mathbf{1}$ & $\mathbf{3}$ & $\mathbf{4}$ \\
\cline { 2 - 5 } & $3,6^{\mathrm{a}}$ & $3,4^{\mathrm{a}}$ & $3,4^{\mathrm{a}}$ & $3,5^{\mathrm{a}}$
\end{tabular}

Superskrip yang sama pada baris yang sama menunjukkan berbeda nyata $(\mathrm{P}>0,05)$.

Data analisis sidik ragam menunjukkan bahwa pemberian jenis pupuk yang berbeda tidak berpengaruh secara nyata $(\mathrm{P}>0,05)$ terhadap variable lebar daun. Lebar daun hasil penelitian lebih tinggi dibanding hasil penelitian Lasamadi (2013) yakni $(2,64-3,24) \mathrm{cm}$. Namun sama dengan hasil lebar daun yang dihasilkan pada penelitian Sirait, A. Tarigan dan K. Simanihuruk (2015) yang menghasilkan $(3,6-3,8) \mathrm{cm}$.

\section{Jumlah Daun}

Rata - rata jumlah daun yang diperoleh saat penelitian disajikan pada tabel di bawah ini:

\begin{tabular}{ccccc}
\hline \multirow{3}{*}{ Jumlah Daun } & \multicolumn{4}{c}{ Perlakuan } \\
\cline { 2 - 5 } & $\mathbf{1}$ & $\mathbf{2}$ & $\mathbf{3}$ & $\mathbf{4}$ \\
\cline { 2 - 5 } & $84^{\mathrm{a}}$ & $79,3^{\mathrm{a}}$ & $73,8^{\mathrm{a}}$ & $66,8^{\mathrm{a}}$ \\
\hline
\end{tabular}

Superskrip yang sama pada baris yang sama menunjukkan berbeda nyata $(\mathrm{P}>0,05)$.

Jumlah daun rumput Pennisetum purpureum $c v$. Mott tidak dipengaruhi secara nyata (P > $0,05)$ oleh perlakuan jenis pupuk yang berbeda. Jumlah daun tertinggi yang dihasilkan diperoleh dari perlakuan kontrol tanpa pupuk. Jumlah daun pada saat penelitian hampir sama dengan jumlah daun yang dihasilkan pada penelitian Kusuma (2014) yakni (54, 3 - 80, 2) helai.

\section{KESIMPULAN}

Perlakuan jenis pupuk yang berbeda tidak berpengaruh secara nyata $(P>0,05)$ terhadap variable pengamatan yang meliputi indeks hijau daun, berat segar, berat kering matahari, jumlah anakan, lingkar batang, lingkar rumpun, tinggi tanaman, panjang daun, lebar daun, serta jumlah daun.

Hal ini dapat dikarenakan unsur nitrogen dalam pupuk yang diberikan pada tanaman disetarakan, yakni $115 \mathrm{~kg}$ nitrogen murni per hektar lahan. Selain itu dapat pula disebabkan oleh pupuk kandang (kotoran kambing) yang digunakan sebagai media tanam mampu mensuplai kebutuhan hara tanaman.

\section{DAFTAR PUSTAKA}

Gani. A. 2007. Bagan Warna Daun (BWD). Balai Besar Penelitian Tanaman Padi. https://dpi.nsw.gov.au/_data/assets/pdf_file/0008/199457/Ses3_Leaf_colour_chart. pdf. [Diunduh pada 28 Januari 2017]. 
Kusuma. M. E. 2014. Respon Rumput Gajah (Pennisetum purpureum) Terhadap Pemberian Pupuk Majemuk. Jurnal Ilmu Hewani Tropika 3 (1):6 - 11.

Lasamadi. R. D., dkk. 2013. Pertumbuhan dan Perkembangan Pennisetum purpureun Cv. Mott yang Diberi Pupuk Organik Hasil Fermentasi EM4. Jurnal Zootek 32 (5): 158 $-171$.

Lembah Gogoniti Farm. Petunjuk Teknis Penanaman Rumput Gajah Odot. https://download.lembahgogoniti.com/brosur_odot.pdf [Diunduh pada 15 Januari 2017].

Paat. P. C., dan Taulu. L. A. 2012. Introduksi Tanaman Pakan Unggul Pennisetum purpureum Schum cv. Mott di Sentra Produksi Sapi Potong di Sulut. Seminar Nasional Teknologi Peternakan: 384 - 392.

Palupi. 2011. Fungsi Unsur Hara Bagi Tanaman. Diunduh di http://www.novapdf.com [Diunduh 23 Januari 2017].

Rellam. C. R., dkk. 2017. Pengaruh Naungan danPemupukan Nitrogen Terhadap Karakteristik Morfologis Rum[ut Gajah Dwarf (Pennisetum purpureum cv. Mott. Jurnal Zootek 37 (1): 179 - 185.

Sandiah. N., Pasolon. Y. B., dan Sabaruddin. L. O. 2011. Uji Keseimbangan Hara dan Variasi Jarak Tanam Terhadap Pertumbuhan dan Produksi Rumput Gajah (Pennisetum purpureum var. Hawaii). Agriplus 21 (2):94 - 100.

Santia, Anis. S. D., dan Kaunang. C. L. 2017. Pengaruh Tinggi dan Jarak Waktu Pemotongan Rumput Gajah Dwarf (Pennisetum purpureum cv. Mott) Terhadap Pertumbuhan Vegetatif dan Produksi Bahan Kering. Jurnal Zootek 37 (1):116 - 122.

Siahaya. L. 2007. Penanaman dan Pemeliharaan Pelatihan Penanaman Hutan di Maluku dan Maluku Utara. Fakultas Pertanian Universitas Pattimura: 76 - 98.

Sigar. N. V. P., dkk. 2014. Pengaruh Pemberian Pupuk N-P-K Terhadap Bahan Kering dan Protein Kasar Rumput Brachiaria humidicola cv. Trully dan Pennisetum purpureum cv. Mott. Jurnal Zootek Vol 34 (2): 109 - 113.

Sirait J., A Tarigan., dan K Simanihuruk. 2015. Karakteristik Morfologi Rumput Gajah Kerdil (Pennisetum purpureum cv. Mott) pada Jarak Tanam Berbeda di Dua Agroekosistem di Sumatera Utara. Prosiding Seminar Nasional Teknologi Peternakan: $643-649$.

Steel R. G. D., and Torrie J. H., 1995. Prinsip dan Prosedur Statistika: Suatu Pendekatan Biometrik. Sumantri, B. Penerjemah. Jakarta: PT. Gramedia Pustaka Utama. Terjemahan Dari Principles and Procedures of Statistics.

Sugeng. B. 2007. Sapi Potong. Penebar Swadaya: Jakarta.

Wikipedia. 2017. Pupuk Organik_Wikipedia Bahasa Indonesia, Ensiklopedia Bebas. https://id.m.wikipedia.org.wiki/pupuk_organik [Diakses 19 September 2017]. 
Yani. A. 2008. Penggunaan Pupuk Lengkap Cair Terhadap Pertumbuhan, Kadar Bahan Kering, Bahan Organik Dan Protein Kasar Rumput Gajah. Naskah Publikasi Lembaga Penelitian Universitas Muhammadiyah Malang.

Zahroh F., Muizzudin, dan Chamisijatin. L. 2016. Pengaruh Jenis dan Dosis Pupuk Kandang terhadap Tinngi Tanaman, Luas Daun, dan Berat Basah Rumput Gajah Odot (Pennisetum purpureum cv. Mott). Prosiding Seminar Nasional II: 908 - 914.

Zahro. L., Cahyono B., Hastuti R. B. 2009. Profil Tampilan Fisik dan Kandungan Kurkuminoid dari Simplisida Temulawak (Curcuma Xanthorrhiza Roxb) pada beberapa Metode Pengeringan. Jurnal Sains dan Matematika 17 (1): 24 - 32. 